\title{
MODEL TGT BERBANTUAN MEDIA PERMAINAN PLETOKAN UNTUK MENINGKATKAN KEMAMPUAN BERPIKIR KRITIS SISWA SEKOLAH DASAR
}

\author{
Nita Mustika Sari, Siti Masfuah, Sekar Dwi Ardianti \\ Prodi PGSD, FKIP Universitas Muria Kudus, Indonesia \\ 201633072@std.umk.ac.id
}

\begin{abstract}
This study aims to describe the TGT model assisted by petting games to improve students' critical thinking skills. This class action research will be carried out in class IV SDN Pati Wetan 03 with research subjects 35 students and teachers planned in 2 cycles. Data collection techniques in this study were observation, interview, documentation, and test techniques. Analysis of the data used is quantitative and qualitative analysis. Results Increased student learning activities attitudes in the first cycle of 75.5 and increased in the second cycle to 80.5. Whereas the students' learning activities aspects of skills in the first cycle amounted to 70.5 and increased in the second cycle to 79.7. Increased students' critical thinking skills in the first cycle by 70.2 and increased in the second cycle to 81.6. The results of the study can be concluded that the results of the application of the model assisted by plete playing media can improve students' critical thinking skills.

Keywords: Teams Games Tournament, Pletokan Games, Critical Thinking Ability
\end{abstract}

\begin{abstract}
ABSTRAK
Penelitian ini bertujuan untuk mendeskripsikan model TGT berbantuan permainan pletokan untuk meningkatkan kemampuan berpikir kritis siwa. Penelitian tindakan kelas ini akan dilaksanakan di kelas IV SDN Pati Wetan 03 dengan subjek penelitian 35 siswa dan guru yang direncanakan dalam 2 siklus. Teknik pengumpulan data pada penelitian ini adalah teknik observasi, wawancara, dokumentasi, dan tes. Analisis data yang digunakan adalah analisis kuantitatif dan kualitatif. Hasil Peningkatan aktivitas belajar siswa aspek sikap pada siklus I sebesar 75,5 dan meningkat pada siklus II menjadi 80,5. Sedangkan pada aktivitas belajar siswa aspek keterampilan pada siklus I sebesar 70,5 dan meningkat pada siklus II menjadi 79,7. Peningkatan kemampuan berpikir kritis siswa pada siklus I sebesar 70,2 dan meningkat pada siklus II menjadi 81,6. Hasil penelitian dapat disimpulkan bahwa hasil penerapan model tgt berbantuan media permainan pletokan dapat meningkatkan kemampuan berpikir kritis siswa.

Kata Kunci: Teams Games Tournament, Permainan Pletokan, Kemampuan Berpikir Kritis
\end{abstract}

Submitted Jul 30, 2020 | Revised Aug 6, 2020 | Accepted Aug 9, 2020

\section{Pendahuluan}

Salah satu cara yang dapat ditempuh dalam pembelajaran yang inovasi adalah pendidik harus mempunyai kemampuan dalam mengembangkan berpikir kritis siswa. Susanto (2013:121) mengemukakan bahwa berpikir kritis adalah suatu tindakan dengan cara berpikir tentang ide yang berhubungan dengan konsep atau masalah yang dipaparkan. Fisher dan scriven (dalam Fisher, 2009:10) mengungkapkan bahwa berpikir kritis adalah pemahaman dan evaluasi yang terampil dan aktif terhadap pengamatan dan komunikasi, informasi dan argumentasi. Berdasarkan beberapa pendapat para ahli diatas dapat disimpulkan bahwa berpikir kritis adalah suatu proses berpikir tentang suatu pemikiran atau berpendapat yang berhubungan dengan rencana atau permasalahan yang harus dikembangkan karena bisa mempengaruhi keberhasilan pada proses pembelajaran dan hasil belajar siswa. Ennis (dalam Susanto, 2013:125) mengungkapkan bahwa indikator berpikir kritis diantaranya yaitu (1) memberikan penjelasan sederhana, (2) membangun keterampilan dasar, (3) menyimpulkan, (4) memberikan penjelasan lanjut, dan (5) mengatur strategi dan taktik.

Hasil observasi dan wawancara yang telah dilakukan pada tanggal 1 November 2019 di SDN Pati Wetan 03 dengan guru kelas IV, mendapat hasil bahwa berpikir kritis siswa di kelas IV pada saat pembelajaran rendah. Aktivitas siswa dalam pembelajaran masih kurang bisa memperhatikan guru, 
masih suka bercanda dan menganggap pembelajaran bersifat teoritis dan hafalan sehingga siswa menjadi kurang antusias dalam mengikuti pembelajaran. Permasalahan tersebut akan memberikan dampak kurangnya berpikir kritis siswa sehingga hasilnya kurang maksimal, apabila berpikir kritis siswa rendah, dapat dikatakan bahwa tujuan pembelajaran belum tercapai.

Hal lainnya dapat dibuktikan dengan hasil tes prasiklus yang dilakukan pada hari tersebut. Berdasarkan hasil tes prasiklus kemampuan berpikir kritis siswa masih rendah. Hal ini ditunjukkan berdasarkan hasil tes prasiklus yang dilakukan di kelas IV dengan jumlah jumlah 35 siswa, tidak terdapat siswa yang mendapatkan kategori sangat baik, terdapat 1 siswa $(2,85 \%)$ yang mendapatkan kategori baik, 3 siswa $(8.57 \%)$ berada dalam kategori cukup dan 31 siswa $(88,5)$ dalam kategori perlu bimbingan. Banyaknya nilai yang belum mencukupi KKM ini bisa disebabkan guru dalam menyampaikan pembelajaran yang masih menekankan konsep-konsep yang terdapat di dalam buku dan juga belum memanfaatkan pendekatan lingkungan dalam pembelajaran secara maksimal. Berdasarkan permasalahan tersebut peneliti memberikan solusi yaitu selayaknya dalam pembelajaran dilakukan suatu inovasi dengan mengajak siswa lebih aktif, tertantang, dan melatih siswa untuk dapat bekerja secara berkelompok yaitu dengan menerapkan model pembelajaran Times Games Tournament (TGT) dengan berbantuan media permainan pletokan media permainan pletokan.

Teknik model pembelajaran TGT ini siswa diharapkan dapat memberi kesempatan untuk bekerja sendiri serta bekerja sama dengan orang lain yang melibatkan siswa secara aktif dan membangun tanggung jawab pribadi dan tanggung jawab kelompok. Slavin (2010:163) mengemukakan TGT adalah model pembelajaran kooperatif menggunakan turnamen akademik dan menggunakan kuis-kuis dan system skor kemajuan individu, di mana para siswa berlomba sebagai wakil tim mereka dengan anggota tim lain yang kinerja akademik sebelumnya setara seperti mereka. Slavin (2010: 170) Times Games Tournament (TGT) terdiri dari siklus regular dari aktivitas pengajaran, sebagai berikut: a) Pengajaran, b) belajar tim, c) game, d) turnamen, e) penghargaan.

Selain menggunakan model TGT agar kemampuan berpikir kritis meningkat yaitu dengan menggunakan media pembelajaran. Salah satu media yang dapat digunakan adalah media permainan tradisional pletokan. Permainan tradisional pletokan ini dapat berdampak positif bagi siswa, karena permainan dianggap menyenangkan, dan motivasi belajar siswa. Permainan tradisional pletokan ini dipilih karena permainan ini tidak asing lagi di kalangan peserta didik. Pletokan adalah sebuah nama senjata mainan yang terbuat dari bambu, dan pelurunya terbuat dari kertas yang dibasahkan, atau biji jambu atau kembang.

Pelaksanaan Model TGT dan permainan tradisional pletokan pada penelitian ini dilaksanakan pada muatan Ilmu Pengetahuan Alam (IPA) dan Bahasa Indonesia. Penelitian yang sesuai dengan penelitian ini adalah Arini, dkk (2013) mendapatkan hasil bahwa penerapan model TGT dapat meningkatkan kemampuan berpikir kritis dan hasil belajar siswa. Hasil penelitian Mulyani, dkk., (2018) menunjukkan bahwa penerapan model pembelajaran TGT telah berhasil meningkatkan kemampuan kerja sama. Penelitian lain yang dilakukan Sasono, dkk., (2018) mendapatkan hasil bahwa penerapan media permainan dapat meningkatkan berpikir kritis. Demikian juga dengan penelitian yang dilakukan Kumala, (2016) juga menunjukkan bahwa penerapan model inkuiri denganmenggunakan permainan tradisional dapat meningkatkan prestasi belajar siswa.

Berdasarkan uraian diatas, tujuan penelitian ini untuk mendeskripsikan peningkatan kemampuan berpikir kritis menggunakan model TGT berbantuan media permainan pletokan pada siswa kelas IV SDN Pati Wetan 03.

\section{Metode Penelitian}

Rancangan dalam penelitian ini berbentuk Penelitian Tindakan Kelas (PTK). Penelitian tindakan kelas merupakan penelitian yang dilaksanakan secara bersiklus untuk memecahkan permasalahan di dalam kelas, sehingga proses belajar mengajar menjadi lebih bermakna. PTK adalah 
suatu pencermatan terhadap kegiatan yang sengaja dimunculkan, dan terjadi dalam sebuah kelas (Arikunto 2010:130). Penelitian ini dilaksanakan 2 siklus dan masing-masing siklus meliputi perencanaan, pelaksanaan, pengamatan, dan refleksi. Bagan model penelitian menurut Kemmis dan McTaggart dalam Arikunto (2010:134) digambarkan pada Gambar 1.

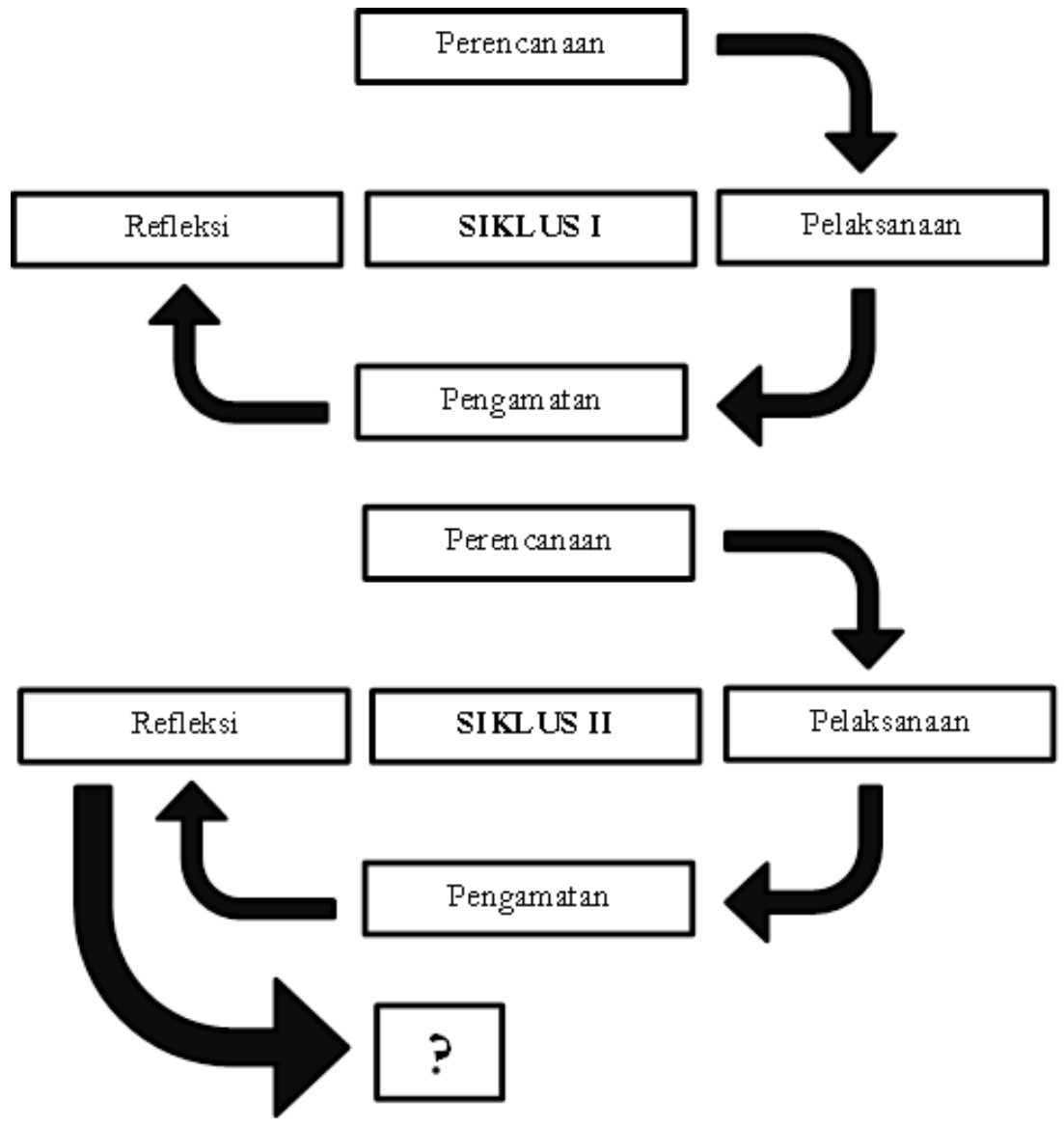

Gambar 1. Gambar Model PTK (Kemmis dan McTaggart)

Sumber : Arikunto (2010:134)

Penelitian tindakan kelas ini dilaksanakan di kelas IV SDN Pati Wetan 03. Subjek penelitian ini adalah siswa kelas IV dengan jumlah 35 siswa yang terdiri dari 20 siswa laki-laki dan 15 siswa perempuan. Teknik pengumpulan data menggunakan observasi dan tes. Observasi untuk mengetahui keterlaksanaan pembelajaran. Sedangkan, tes untuk mengukur kemampuan berpikir kritis siswa. Instrumen yang digunakan adalah lembar observasi dan lembar tes kemampuan berpikir kritis siswa. Analisis data dilakukan dengan teknik analisis data kuantitatif dan teknik analisis data kualitatif.

\section{Hasil dan Pembahasan}

Penelitian tindakan kelas melalui Model TGT Berbantuan Media Permainan Pletokan untuk Meningkatkan Kemampuan Berpikir Kritis Siswa Sekolah Dasar dilaksanakan dalam 2 siklus. Tes evaluasi berpikir kritis siswa berupa soal uraian sebanyak 10 soal dimana 2 soal mewakili indikator berpikir kritis. Berdasarkan hasil perhitungan pada lembar pengamatan untuk setiap siklusnya. Indikator Berpikir Kritis siswa meliputi (1) Memberikan penjelasan sederhana, (2) Membangun keterampilan dasar, (3) Menyimpulkan, (4) Memberikan penjelasan lanjut, dan (5) Mengatur strategi dan taktik. Pada penelitian tindakan kelas ini kemampuan berpikir kritis mengalami peningkatan seperti terlihat pada Gambar 1 berikut ini: 


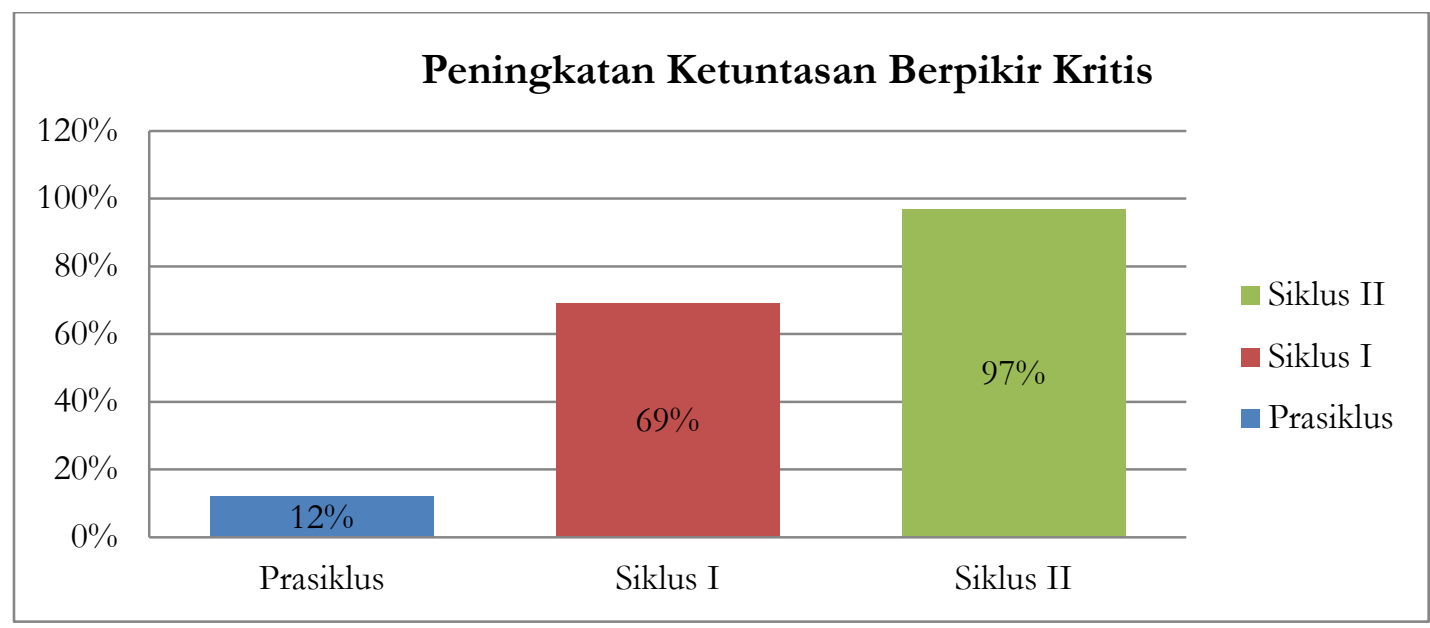

Gambar 1. Peningkatan Ketuntasan Berpikir Kritis

Gambar 1 menunjukkan bahwa ketuntasan persentase rata-rata berdasarkan hasil yang telah diperoleh dari kemampuan berpikir kritis siswa menggunakan model Teams Games Tournament (TGT) berbantuan media permainan pletokan telah mencapai peningkatan pada siklus I ke siklus II. Guru Ketuntasan persentase klasikal yang dihasilkan dari prasiklus memperoleh persentase $12 \%$ dengan kriteria perlu bimbingan. Setelah diterapkan dengan menggunakan model Teams Games Tournament (TGT) berbantuan media permainan pletokan telah mengalami peningkatan dengan persentase $69 \%$ kriteria perlu bimbingan dan mengalami peningkatan pada siklus 2 dengan persentase 97\% kriteria sangat baik. Beberapa penelitian yang sesuai dengan penelitian ini adalah Maqbullah, dkk (2018) dalam penelitiannya mendapatkan hasil bahwa menggunakan model pembelajaran dapat meningkatkan kemampuan berpikir kritis siswa.

Setelah itu peneliti menganalisis kemampuan berpikir kritis siswa pada setiap indikator. Hasil tes evaluasi berpikir kritis siklus I dan siklus II setiap indikator dapat dilihat pada Gambar 2.

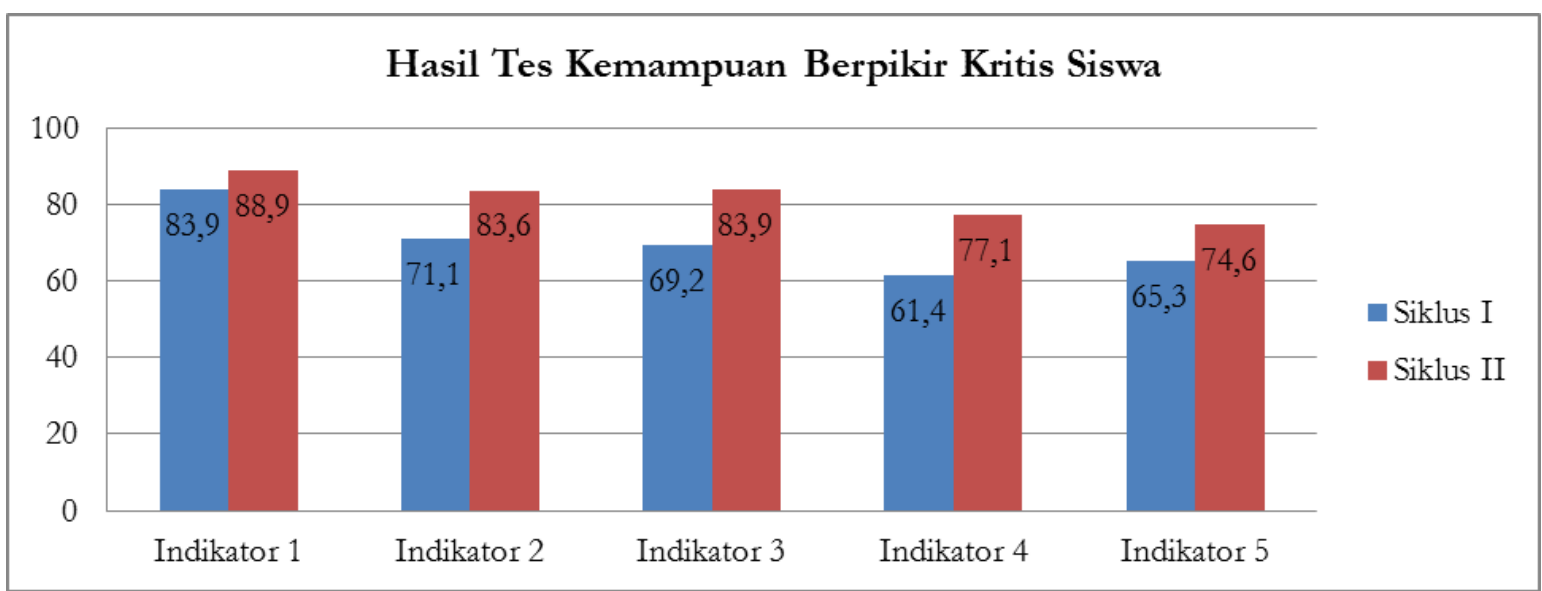

Gambar 2. Hasil Tes Evaluasi Kemampuan Berpikir Kritis Siswa

Gambar 2 menunjukkan bahwa Indikator 1 yaitu memberikan penjelasan sederhana, hasil tes kemampuan berpikir kritis pada siklus I memperoleh rata-rata nilai 83,9 dengan kriteria baik dan meningkat pada siklus II rata-rata nilai 88,9 dengan kriteria baik. Pada siklus I siswa belum mampu menjelaskan dikarenakan siswa tidak memperhatikan penjelasan dari guru dan hanya mampu menjelaskan dengan singkat. Pada siklus II dengan memberikan contoh dalam penyampaian materi menggunakan bahasa yang sederhana dan jelas siswa sudah mampu memberikan penjelasan secara logis, namun masih ada siswa yang mengalami kesulitan. Hal ini sependapat dengan Sulistiani, dkk 
(2016) Kemampuan memberikan penjelasan sederhana berkaitan dengan bagimana siswa mampu mendefinisikan apa yang diketahui maupun tidak dengan cara bertanya maupun menjawab suatu penjelasan maupun tantangan.

Indikator 2 yaitu membangun keterampilan dasar, hasil tes kemampuan berpikir kritis pada siklus I memperoleh rata-rata nilai 71,1 dengan kriteria cukup dan meningkat pada siklus II rata-rata nilai 83,6 dengan kriteria baik. Siklus I siswa masih ada yang kurang teliti dalam menyelesaikan pertanyaan. Kurang mampu memikirkan apakah sumber yang diperoleh dapat dipercaya. Kemudian terjadi peningkatan pada siklus II dengan memotivasi dan meminta untuk mencatat hal-hal penting sehingga siswa sudah mulai bisa mempertimbangkan jawaban yang diberikan. Hal ini sependapat dengan Hidayah, dkk (2019) menjelaskan bahwa berpikir kritis merupakan pemikiran yang masuk akal, mendalam, terampil dan reflektif terhadap masalah yang telah terjadi.

Indikator 3 yaitu menyimpulkan, hasil tes kemampuan berpikir kritis pada siklus I memperoleh rata-rata nilai 69,2 dengan kriteria perlu bimbingan dan meningkat pada siklus II rata-rata nilai 83,9 dengan kriteria baik. Pada siklus I siswa masih rendah dalam menyimpulkan dengan menggunakan kalimatnya sendiri dan masih terpacu pada kalimat-kalimat yang terdapat di dalam buku. Kemudian terjadi peningkatan di siklus II dengan memotivasi siswa untuk memahami dan menguraikan sehingga siswa sudah mampu membuat kesimpulan dengan menggunakan kalimatnya sendiri. Hal ini sependapat dengan Yuliana (2015) bahwa keterampilan menyimpulkan menuntut siswa agar mampu menguraikan dan memahami berbagai aspek secara bertahap agar sampai kepada sebuah simpulan.

Indikator 4 yaitu memberikan penjelasan lanjut, hasil tes kemampuan berpikir kritis pada siklus I memperoleh rata-rata nilai 61,4 dengan kriteria perlu bimbingan dan meningkat pada siklus II ratarata nilai 77,1 dengan kriteria cukup. Pada siklus I siswa masih kurang dalam memberikan suatu penjelasan berupa argumen-argumen. Kemudian terjadi peningkatan pada siklus II dengan mengajak siswa untuk saling berpendapat sehingga siswa mampu mengungkapkan argument dengan menanggapi teman lainnya. Hal ini sependapat dengan Anwar, dkk (2016) menjelaskan bahwa berpikir kritis sangat berpengaruh besar terhadap penalaran untuk mengemukakan alasan-alasan dan untuk mengevaluasi penalaran sebaik mungkin.

Indikator 5 yaitu mengatur strategi dan taktik, hasil tes kemampuan berpikir kritis pada siklus I memperoleh rata-rata nilai 65,3 dengan kriteria perlu bimbingan dan meningkat pada siklus II rata-rata nilai 76,6 dengan kriteria cukup. Pada siklus I siswa di minta untuk berpendapat menyelesaikan masalah, tapi siswa kurang mampu mencari alternative dalam pemecahan masalah. Kemudian terjadi peningkatan pada siklus II dengan mempersilahkan siswa untuk melakukan percobaan dengan kelompoknya sehingga siswa dapat memecahkan masalah dan dapat berinteraksi langsung dengan teman-temanya. Hal ini sependapat dengan Masfuah dan Pratiwi (2020) yang menyatakan bahwa berpikir kritis adalah salah satu kemampuan yang digunakan untuk memecahkan masalah dalam kehidupan manusia.

Dari penelitian ini dapat disimpulkan bahwa terdapat peningkatan kemampuan berpikir kritis siswa melalui model Teams Games Tournament (TGT) berbantuan media Permainan pletokan dari prasiklus, siklus I, dan siklus II. Jadi, penelitian tindakan kelas ini dikatakan berhasil dengan kriteria baik.

\section{Kesimpulan}

Berdasarkan hasil penelitian tindakan kelas yang telah dilaksanakan dapat disimpulkan bahwa model model Teams Games Tournament (TGT) berbantu media Permainan pletokan dapat meningkatkan kemampuan berpikir kritis siswa kelas IV SDN Pati Wetan 03. Pada siklus I diperoleh rata-rata sebesar 70,2 dengan kriteria cukup dan meningkat pada siklus II menjadi 81,6 dengan kriteria baik. 


\section{Daftar Pustaka}

Anwar, E.K., Husnaepi. dan Royani, I. (2015). Pengaruh Model Pembelajaran Kooperatif Tipe TGT terhadap Kemampuan Berpikir Kritis Siswa. Jurnal Ilmiah Biologi (Bioscientist), 3 (1), 18-26.

Arikunto, Suharsini., dkk. (2010). Penelitian Tindakan Kelas. Jakarta: Bumi Aksara.

Arini., N.W., Rusnadi., N.M. dan Parmiti, D.P. (2013). Penerapan Model Pembelajaran Kooperatif Tipe Team Games Tournament untuk Meningkatkan Kemampuan Berpikir Kritis dan Hasil Belajar IPA. Mimbar PGSD Undiksha. 1 (1), 9-10.

Fisher, A. (2008). Berpikir Kritis: Sebuah Pengantar. Jakarta: Erlangga.

Hidayah, R.N., Sulasmono, B.S. dan Widyanti, E. (2019). Penerapan Model Pembelajaran Think Pair Share dengan Permainan Puzzle untuk Meningkatkan Kemampuan Berpikir Kritis Matematika Kelas IV SD. Jurnal Teori dan Aplikasi Matematika (JIAM). 3 (1), 34-39.

Hamalik, Oemar. (2012). Kurikulum dan Pembelajaran. Jakarta: Bumi Aksara.

Kumala. (2016). Penerapan model Pembelajaran Inkuiri Terbimbing Dipadu Permainan Tradisional Cina Buta untuk Meningkatkan Prestasi Belajar siswa kelas IV SDN Ampeldento 01. Proceedings International Seminar FoE (Faculty of Education). 1(1), 324.

Masfuah, S. dan Pratiwi, I. (2020). THE Impact Of Environmental-Carecharacter To Students'critical Thinking Through The Learning Of Socio-Scientific Issue (SSI) With Pictorial Riddle Method. International Conference On Education, 1 (1) 1-7.

Maqbullah, S. Sumiati, T. dan Muqodas, I. (2018). Penerapan Model Problem Based Learning untuk Meningkatkan Kemampuan Berpikir Kritis pada Pembelajaran IPA di Sekolah Dasar. Metodik Didaktik, 13 (2), 106-112.

Mulyani, R., Djumhana, N., dan Syarifudin, T. (2018). Penerapan Model Pembelajaran Kooperatif Team Games Tournament (TGT) untuk Meningkatkan Kemampuan Kerja Sama Siswa Sekolah Dasar. Jurnal Pendidikan Guru Sekolah Dasar. 3 (2), 38-45.

Sasono, M., Nabila, N.I., dan Purwandari. (2018). Pengembangan Media Pembelajaran Congklak Dilengkapi Kartu Soal Untuk Meningkatkan Kemampuan Berpikir Kritis Siswa SMP. Prosiding Seminar Nasional Pendidikan Fisika, 1(1): 154-157.

Slavin, Robert. (2010). Cooperative Learning Teori, Riset dan Praktik. Bandung: Nusa Media

Sulistiani, e., Budiarti, R.S. dan Muswita. (2016). Analisis Kemampuan Berpikir Kritis Siswa Lintas Minat pada Pembelajaran Biologi Kelas X IIS SMA Negeri 11 Kota Jambi. Jurnal Pendidikan Sekolab Dasar, 2 (1), 1-19.

Susanto, Ahmad. (2013). Teori Belajar dan Pembelajaran di Sekolah Dasar. Jakarta: Prenadamedia Group.

Yuliana. (2015). Pengaruh Penerapan Model Pembelajaran Controversial Issues Terhadap Kemampuan Berpikir Kritis Siswa pada Mata Pelajaran PPKn di SMA Negeri 1 Prabumulih. Jurnal BhinnekaTunggal Ika. 2 (2), 148-156 